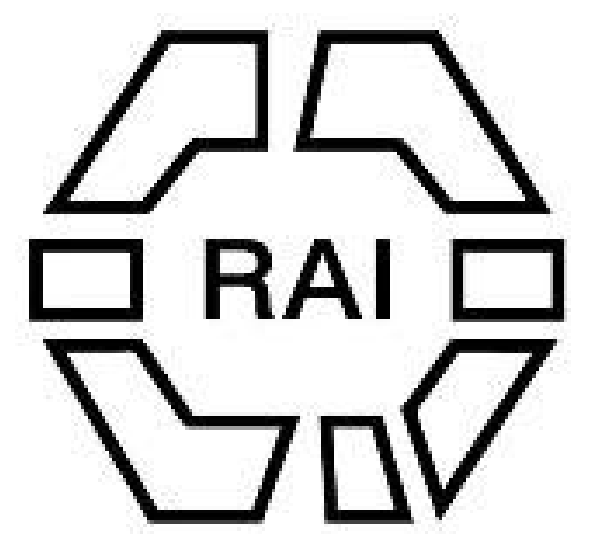

\title{
WILEY
}

\section{Proverbs of the Ouraons}

Author(s): A. Tiger

Source: Man, Vol. 13 (1913), pp. 57-58

Published by: Royal Anthropological Institute of Great Britain and Ireland

Stable URL: http://www.jstor.org/stable/2788106

Accessed: 27-06-2016 07:16 UTC

Your use of the JSTOR archive indicates your acceptance of the Terms \& Conditions of Use, available at

http://about.jstor.org/terms

JSTOR is a not-for-profit service that helps scholars, researchers, and students discover, use, and build upon a wide range of content in a trusted digital archive. We use information technology and tools to increase productivity and facilitate new forms of scholarship. For more information about JSTOR, please contact support@jstor.org.

Royal Anthropological Institute of Great Britain and Ireland, Wiley are collaborating with JSTOR to digitize, preserve and extend access to Man 
Dreading ridicule he attempted to murder his wife and committed suicide. The woman, however, recovered. himself.

3. Another man finding he had been robbed of Rs. 70 during the night hung

4. A woman recently threw herself in front of the train and was killed. Her husband did not know why she did it, but as he said : "I was quite near, yet I could " not prevent the act as $I$ did not know if she were doing it because she was angry " with me. For if she was doing it for that reason and I had touched her I should " certainly have died."

5. The mother of one of my porters hanged herself after bearing an excruciating pain in her foot for two days.

6. A woman hanged herself at Lamuru after a quarrel with her husband.

In conclusion I will quote the words of Karanja mentioned above :-

"It is very common for A-Kikuyu to kill themselves. Some do so because they are old and solitary and have no relations, others because they are poor.

"It is more common for women to kill themselves than men-many, many women have killed themselves.

"None of the relatives or members of the clan may touch the corpse of a suicide. The unrelated elders of the kiama (council) are those who cut down the body of one who has hanged himself, and they are given a very fat sheep indeed for their trouble."

MERVYN W. H. BEECH, M.A.

India, North.

Proverbs of the Ouraons. By A. Tiger.

Tiger.

1. Among men the barber, among animals the monkey, among birds the crow is very prudent.

2. The blind 100 times; the one-eyed man 1,000 times; the squint-eyed man 10,000 times more cunning than an ordinary man.

3. An orphan child is easily provoked.

4. An illegitimate child is very clever.

5. The very dog which I tamed bites me.

6. We must not count the teeth of a presented horse.

7. A fool gets wet when he is in the village.

8. Thunder and lightning seldom brings rain.

9. Day and night is the same for a blind man whether he sleeps or awakes.

10. A distant drum is very pleasant.

11. You have attained old age and you don't know what a goat is. father.

12. Take care if you fall from the tree, you will see the wedding of your

13. One egg and that also spoilt.

14. You have not lost yet your milk teeth.

13. A child which sucks the milk of its mother is a good one.

16. A thief at mid-day.

17. A thief knows thieves.

18. A dog is very bold when it is in the house.

19. No one accepts a truth, but a lie the whole world believes.

20. If the reputation of a man is good then the whole world is good.

21. A big man's share is big, a small man's small.

22. He who comes last returns empty handed.

23. A word spoken cannot be called back.

24. A good beginning is half the work done. 
25. Money is the father of men.

26. Danger past, Ram (God) is forgotten.

27. What early grows early rots.

28. As is the father such is the son.

29. To buy dear and to sell cheap.

30. To get drowned in a dry river.

31. A joker must not be hanged.

32. To wash a piece of charcoal with soap.

33. He who works not must not eat.

34. If you sit with clean hands you will get nothing.

35. To lick the spittle.

36. Not to dream properly. (To explain an accident that happened afterwards.)

37. He who does not follow the advice of his elder will go to beg.

38. Drop by drop a tank is filled.

39. When stomach is full everything is dust.

40. A daughter is but others' property.

41. A hunter looks for a gun when a deer is before him.

42. An idle fellow after falling into the pit does not want to come out.

43. One pea was divided between seven brothers.

44. Time once past never returns.

45. A tiger was caught in the cobweb.

46. Filter the water before you drink.

A. TIGER.

\section{REVIEWS.}

India : Assam.

Shakespear.

The Kuki-Lushei Clans. By Lt.-Colonel J. Shakespear, C.I.E., D.S.O.

London : Macmillan \& Co., 1912.

This volume is divided into two parts. In Part $I$ we have an account of the Lushei proper; in Part II an account of tribes who have either been practically assimilated by Lusheis under the rule of Thangur chiefs or have been much influenced by their neighbours as well as of the so-called old and new Kukis and of the Lakhers, comparatively recent immigrants from the Chin Hills. Colonel Shakespear traces firmly and clearly the wars and troubles of these people and their migrations from an area between Tiddim and Falam in the Chin Hills. They fought, now for land, now for the hand of the local Helen, sometimes in resistance to the ever-increasing pressure of the stalwart Chins east of them, sometimes in organised warfare against the Thados. Their affinities are touched on in more than one place. In the Introduction he notes the similarities between the Lusheis and the matrilineal Garos, and approves the theory put forward by Sir Charles Lyall of the evident connection between the Mikirs and the Kuki Chin group. He recurs to this theme on page 8, where he remarks that the Kukis, Chins, and Lusheis, are all of the same race, with definite traces of a relationship with the Kabuis and Manipuris, and in the last chapter of Part II the linguistic evidence is briefly summarised. With his hope that the affinities of the tribes described in this book with other tribes may be dealt with by some competent authority when the whole series has been published, we shall all find ourselves in complete agreement, but will any of us live to see the completion of the series? And what of the North Bank tribes, what of the tribes north and north-east of Manipur? They await their pious historians and they belong to the far-flung Tibeto-Burman peoples. The task is stupendons and yet should be undertaken. Why not by Colonel Shakespear himself ? 